\title{
Dynamic Causal Relationships among GDP, Exports, and Foreign Direct Investment (FDI) in the Developing Countries
}

\author{
Mohsen Mehrara ${ }^{1, \star}$, Amin Haghnejad ${ }^{2}$, Jalal Dehnavi ${ }^{2}$, \\ Fereshteh Jandaghi Meybodi ${ }^{2}$ \\ ${ }^{1}$ Faculty of Economics, University of Tehran, Kargar-e-shomali, Po Box 14166-6445, Tehran, Iran \\ ${ }^{2}$ Department of Economics, School of Economics and Official Sciences, \\ Ferdowsi University of Mashhad, Mashhad, Iran
}

*E-mail address: mmehrara@ut.ac.ir

\begin{abstract}
Using panel techniques, this paper estimates the causality among economic growth, exports, and Foreign Direct Investment (FDI) inflows for developing countries over the period of 1980 to 2008. The study indicates that; firstly, there is strong evidence of bidirectional causality between economic growth and FDI inflows. Secondly, the exports-led growth hypothesis is supported by the finding of unidirectional causality running from exports to economic growth in both the short-run and the long-run. Thirdly, export is not Granger caused by economic growth and FDI inflow in either the short run or the long run. On the basis of the obtained results, it is recommended that outwardoriented strategies and policies of attracting FDI be pursued by developing countries to achieve higher rates of economic growth. On the other hand, the countries can increase FDI inflows by stimulating their economic growth.
\end{abstract}

Keywords: FDI; Exports; Economic Growth; Causality

\section{INTRODUCTION}

Sustainable and broad-based economic growth is one of the most important prerequisites for the developing countries to achieve the Millennium Development Goals (MDGs). Recent studies have shown that a macroeconomic policy Framework conducive to growth is a necessity. However, to achieve and maintain a high growth rate, policy makers need to understand the determinants of growth as well as how policies affect growth. The objective of this study is to investigate the causality among economic growth, Foreign Direct Investment (FDI), and exports in the developing countries. From a political point of view, the results may help to inform economic development policy-makers about possible interactions among the variables to pursue effective policies to promote economic growth. Most of the previous studies in this field suffer from two major problems. Firstly, the majority of these studies employ Granger causality tests in a bivariate framework to examine relationship between the pairs of GDP and FDI, GDP and exports, or exports and FDI, and may therefore, suffer from omitted variable bias. Secondly, most previous studies have analyzed the time 
series or the cross-sectional data, which do not account the country-specific or the timespecific issues, respectively. In fact, as we will see in the literature review below, there are relatively few studies that investigate the causal relations among the three variables simultaneously using panel data techniques while this paper has done this with a focus on more recent data. The remainder of this paper is organized as follows: Section 2 gives a review of both the theoretical and empirical literature. Section 3 describes the data used in the analysis. Section 4 presents the econometric methodology to be applied as well as the empirical results. Finally, concluding remarks is given in Section 5.

\section{THE LITERATURE REVIEW}

\section{1. The theoretical background}

From a theoretical perspective, there are several studies that have investigated FDIGrowth-Exports Nexus:

FDI-Growth Nexus; the theoretical foundations for empirical studies on the relationship between FDI and economic growth are derived from neoclassical and endogenous growth models. In the neoclassical growth models, technological progress and labour growth are exogenous, inwards FDI merely increases the capital accumulation in the receiving country, leading to a transitional increase in per capita income growth but has no long-run growth effect Hsiao and Hsiao (2006). In contrast, in endogenous growth models, FDI is generally assumed to be more productive than domestic investment, since FDI encourages the incorporation of new technologies in the production function of the host economy Borensztein, De Gregorio et al. (1998). In this view, FDI-related technological spillovers offset the effects of diminishing returns to capital and keep the economy on a long-term growth path. Moreover, endogenous growth models imply that FDI can promote long-run growth by augmenting the existing stock of knowledge in the host economy through labour training and skill acquisition, on the one hand, and through the introduction of alternative management practices and organisational arrangements on the other Herzer, Klasen et al. (2006). As discussed in (Balasubramanyam, Salisu et al. (1996); Blomstrom and Kokko (1998), multinational corporations (MNCs) can have a positive impact on human capital in host countries through the training courses they provide to their subsidiaries' local workers.

The training courses influence most levels of employees from those with simple skills to those presenting advanced technical and managerial skills. Research and development activities financed by MNCs also contribute to human capital in host countries and thus enable their economies to grow in the long term. FDI is a composite bundle of capital stock, know how, and technology and can enhance employment opportunities for the people of the host country, reduces the burden of imports on the host countries through import substitution, increases competition in the host country's markets, and provides ready access to the world markets and acts as a conduit for the host country to participate in the globalization process. All these stimulate economic growth in the recipient economy. While the literature largely discuses the importance of FDI to economic growth, one should also realise that economic growth itself could be an important determinant, from among the various determinants, in attracting FDI flows as well. This is due to rapid GDP growth will usually create a shortage or a high level of requirement for needed capital in the host country and hence the host country will demand more FDI by offering attractive, preferential or advantageous terms to attract overseas investors in order to gain more FDI. Furthermore, rapid economic growth in the host country will build the confidence of potential overseas investors who intend to invest 
in the host country Lean (2008). Hence, the high growth rate is also likely to influence the quantum level, type and structure of FDI.

Exports-Growth Nexus; the relationship between Exports and economic growth has received increasing attention from academics and policy markers. In the international trade literature the Export-led Growth hypothesis postulates that export-oriented policies contribute to economic growth. Theoretical rationale for this hypothesis can be summarized as follows; i) Export can be a catalyst for output growth as a component of aggregate output; ii) Export sector may generate positive externalities on non-export sectors through more efficient management styles and improved production techniques Feder (1982); iii) Exports expansion is one of the most important source of foreign exchange that can be used to ease the pressure on the balance of payment and to reduce the impact of external shocks on domestic economy, and improve the country's ability to import the necessary capital and intermediate goods unavailable domestically, leading in turn to economic growth (McKinnon (1964); Balassa (1978); Buffie (1992)); iv) Exports growth increases factor productivity due to gains obtained from increasing returns to scale, by catering to the larger foreign market(Makki and Somvaru (2004)).On the other hand, economic growth may also have effects on export growth. Regarding the Growth-led Export hypothesis, the study by Kaldor (1967) emphasizes the positive impact of output growth on productivity growth through such factors as economies of scale, learning curve effects, increased division of labour, and the formation of new production methods and subsidiary industries (See, also, Lancaster (1980); Krugman (1984)). Jung and Marshall (1985) argue that internal growth mechanisms better explain export growth rather than the reverse. In new trade theory, the market structure and output expansion may trigger significant changes in exports through a process of 'cumulative causation' (Markusen and Venables (1998)). Furthermore, due to the increased growth, the internal market may not cater to the increased production of goods, and exporters have no choice except to look outward to sell their products.

FDI-Exports Nexus; there is also a feedback relationship between Foreign Direct Investment inflows and exports theoretically. The FDI inflows provide channels for transferring advanced technology, promoting managerial skills and knowhow, and facilitating access to new and large foreign markets through information externalities. These spillovers contribute to local firm's exports propensity and performance (See Kudrle and Bobrow (1982); Aitken, Hanson et al. (1997); Lutz and Talavera (2004)). Infusion of new capital from foreign owners, often embodied in both new equipment and production processes, can transform average plants into so-called "best practice" establishments that are better able to compete in international markets. The threat posed by these foreign-owned plants may also stimulate competitor companies to invest in new technologies and implement new management practices because of fears of losing domestic market share to the more rapidly innovating and more efficient plants of foreign ownership. As a consequence of this interfirm competition, greater industry-wide competitiveness is achieved with a resultant ability to sell in foreign markets that could not previously be penetrated (Leichenko and Erickson (1997)). In contrast, exports may increase FDI by paving the way for FDI by reducing the investors' transaction costs though the knowledge of host country's market structure(Hsiao and Hsiao (2006)). Furthermore, the issue of FDI-Exports Nexus inevitably arises due to the possible connection between FDI inflows and economic growth, and exports and economic growth. 


\section{2. The empirical studies}

There are quite a few empirical studies that focus on the relationship between Foreign Direct Investment (FDI) and economic growth. Nair-Reichert and Weinhold (2000) applied a mixed fixed and random (MFR) panel data estimation coefficient approach to test the existence of causality between FDI and growth using data for 24 developing countries from 1971 to 1995 . They concluded that there is some evidence that the efficacy of FDI in raising future growth rates, although heterogeneous across countries, is higher in more open economies. Chakraborty and Basu (2002) employed a vector error-correction model (VECM) to investigate the causal relationship between FDI and economic growth. Their results report that GDP in India is not Granger caused by FDI; the causality runs more in the opposite direction, from GDP to FDI. Hsiao and Shen (2003) showed that a high level of urbanization is conducive to a positive effect of FDI on growth. Choe (2003) used a panel VAR model to investigate the causal relationships among economic growth, Foreign Direct Investment, and Gross Domestic Investment in 80 countries during the period of 1990-2001. The results indicate that FDI Granger-causes economic growth, and vice versa; however, the effect of growth on FDI is more apparent than the effect of FDI on growth. Using panel of data for 84 countries over the period 1970-99, Li and Liu (2005) found that FDI not only directly accelerates economic growth, but also indirectly through its interaction with human capital.

They also concluded that interaction of FDI with the technology gap has a significant negative effect on economic growth in developing countries. Zhang (2001) examined cointegration and causality between FDI and economic growth for 11 developing countries in East Asia and Latin America using time series data covering the period 1970-1995. The study indicates that FDI Granger causes growth in only five out of these countries. For six countries where there is no cointegration relationship between these two variables, only one country exhibits short-run Granger causality running from FDI to growth. Using data for 69 developing countries in a cross-country regression framework, Borensztein, De Gregorio et al. (1998) concluded that FDI is an important element for transferring the technology and, in turn, promoting the economic growth. However, the higher productivity of FDI holds only when stock of human capital in the host economy is higher than a given threshold. Hansen and Rand (2006) discovered bi-directional causality between GDP and FDI as a percentage of GDP using data for 31 developing countries from 1970 to 2000. They also found that FDI has a permanent impact on GDP, while GDP has no long run impact on FDI. Using data for 32 OECD and non- OECD countries from 1970 to 1990, De Mello (1999) found that the extent to which FDI is growth-enhancing depends on the degree of complementarity and substitution between FDI and domestic investment. Balasubramanyam Salisu et al. (1996) analyzed data for 46 developing countries, and detected the growth effect of FDI is positive for countries that pursue all outwardly oriented trade policy and potentially negative for countries adopting an inwardly oriented policy. Using the panel cointegration framework, Basu Chakraborty et al. (2003) analyzed data for 23 developing countries from 1978 to 1996, and discovered that there is evidence of bi-directional causality between GDP and FDI for more open economies both in the short-run and in the long-run, while the long run causality is unidirectional and runs from GDP to FDI for relatively closed economies. Using data from 1969 to 2000 and the Toda and Yamamoto (1995) specification, Chowdhury and Mavrotas (2006) discovered that it is GDP that causes FDI in the case of Chile and not vice versa, while for both Malaysia and Thailand, there is a strong evidence of bi-directional causality between the two variables. Ericsson and Irandoust (2001) applied the new Granger noncausality procedure developed by Toda and Yamamoto (1995) and Yamada and Toda (1998) to investigate the issue of causality between FDI growth and output growth for the four 
countries, namely Denmark, Finland, Norway, and Sweden. They found that causality is bidirectional in Sweden and uni-directional, running from FDI growth to economic growth, in Norway, while the results could not offer support for the causal link for Finland and Denmark. Dees (1998) discovered that FDI affects China's long-run economic growth through the diffusion of ideas.

The relationship between exports and economic growth also has been empirically investigated in a few studies. Jung and Marshall (1985) estimated the causality between exports and economic growth for 37 developing countries, and found that the export-led hypothesis is supported in only four out of the countries. Biswal and Dhawan (1998) employed the cointegration and the vector error-correction techniques to test the causal relationship between exports and economic growth using data for Taiwan during the period of $1960-1990$. The test results indicate evidence of two-way causality between these two variables. Reppas and Christopoulos (2005) applied fully modified OLS techniques to investigate the relationship between exports and output growth for a sample of 22 less developed Asian and African countries over the period 1969-1999. Their results suggest that output growth causes exports and not the reverse. Using data for 15 Asian countries from 1967 to 1991 Islam (1998) found that export expansion causes growth in two-third of the countries. Shan and Sun (1998) found a bidirectional causal relationship between exports and real industrial output for China in during the period 1987 to 1996. Ekanayake (1999) studied the causal relationship between exports and economic growth in eight Asian developing countries using time series data from 1960-1997. The empirical results reveal a bi-directional causality for seven out of the countries. Love and Chandra (2005) estimated the causal link between exports and economic growth for seven South Asia countries. Their findings indicate that there is evidence of unidirectional causality running from growth to exports in India, Maldives and Nepal, and from exports to growth in Bangladesh and Bhutan. In Pakistan and Sri Lanka no causality in either direction was found. Bahmani-Oskooee and Oyoloa (2007) used the bounds testing approach to investigate relationship between exports and growth for 44 developing countries. The results provide support for the export-led growth hypothesis in $60 \%$ of the countries. Mah (2005) found a bi-directional causality between export expansion and economic growth in China, using data from 1979 to 2001. Balaguer and Cantavella-Jorda (2001) discover a unidirectional causality running from real income to real exports for the Spanish during the twentieth century. Their results also support the export-led growth hypothesis during the period of economic liberalization. A number of researchers have studied the relationship between Foreign Direct Investment and exports. Sharma (2000) found that FDI appears to have statistically no significant impact on export performance of India using data over the period 1970 to 1998. Jun and Singh (1996) explored the causal link between FDI and exports for 11 high FDI recipient countries from 1969 to 1993.

Their findings reveal that in four cases, the causality runs from exports to FDI, and in only one case export is caused by FDI. In the six remaining countries, there is no causality between the two variables. Using monthly data from 1986 to 1999, Zhang and Felmingham (2001) evaluated the causal relationship between FDI inward and exports for China as a whole and also for its provinces. Their empirical evidence indicate that there is evidence of bidirectional causality between the two variables in China as a whole, the high FDI recipients, and the low FDI recipients, while uni-directional causality runs from exports to FDI for the medium FDI recipients. Aizenman and Noy (2006) analyzed data for 81 countries from 1982 to 1998 to investigate intertemporal relationships between FDI and various categories of trade. Their results reveal that most of the linear feedback between the two variables $(81 \%)$ can be accounted for by Granger-causality from FDI to trade openness (50 
$\%)$ and from trade to FDI (31\%). On the other hand, the feedback effects between trade and FDI are stronger in developing than in industrialized countries.

However, few studies have investigated the relationships among the three variables, simultaneously in a multivariate framework. Ekanayake, Vogel et al. (2003) investigated the existence and the nature of the causal relationship among output level, inward FDI and exports across a cross-section of both developed and developing countries (Brazil, Canada, Chile, Mexico, and United States) using data from 1960-2001. They discovered that there is evidence of two-way causality between exports growth and economic growth. According to the study, the causality results for FDI-growth and FDI-Exports links are mixed. Liu, Burridge et al. (2009) applied the vector error correction model (VECM) to test the causality relationships among trade, FDI and economic growth in nine Asian economies from 1970 to 2002. They discovered bidirectional causality among trade, inward FDI, GDP, and inward merger and acquisitions (M\& As) for most of the sample economies. Liu et al. (2002) found evidence of bidirectional causality between each pair of real GDP, real exports and real FDI for China using quarterly data from 1981:1 to 1997:4. Using data for Thailand from 1970 to 1999, Kohpaiboon (2003) found that the growth impact of FDI tends to be greater under an export-promotion trade regime compared to an import-substitution regime. Hsiao and Hsiao (2006) applied both time series and panel data techniques to investigate the causal relationships among GDP, exports, and FDI in eight rapidly developing East and Southeast Asian economies during the period of 1986-2004. They found different causality results for each economy, and did not identify systematic causality among the variables. Alguacil, Cuadros et al. (2002) estimated the existence of causality among exports, FDI and growth in Mexico during the period of 1980.I-1999.IV. They found that Granger causality runs from exports and FDI to GDP, and also from FDI and GDP to exports.

\section{DATA}

The dataset used in this study cover a cross-section of 57selected developing countries* on the basis of data availability for the time period 1980 - 2008. The data on per capita gross domestic product (GDP), measured in constant 2000 US\$, and Exports of goods and services (EX), as percent of gross domestic product, are taken from the World Bank's World Development Indicators (WDI) CD ROM 2008, while data on per capita foreign direct investment (FDI) inflow is obtained from the United Nations Conference on Trade and Development (UNCTAD) database available online at www.unctad.org. This variable is deflated using US GDP deflator data from the International Monetary Fund (IMF) online database.

\footnotetext{
The selected countries include: Algeria- Argentina- Bangladesh- Benin- Bolivia- Botswana- Brazil- Burkina Faso- Cameroon- ChadChile- China- Colombia- Costa Rica- Cote d'Ivoire- Dominican Republic- Ecuador- Egypt, Arab Rep- El Salvador- Ghana- GuatemalaHonduras- India- Indonesia- Iran, Islamic Rep- Jordan- Kenya- Lesotho- Madagascar- Malawi- Malaysia- Mali- Mauritania- MauritiusMexico-Morocco- Mozambique-Nicaragua- Nigeria- Pakistan- Panama- Paraguay- Peru- Philippines- Rwanda- Senegal- South Africa - Sri Lanka- Sudan- Swaziland- Syrian Arab Republic- Thailand- Togo- Uruguay- Venezuela, RB- Zambia- Zimbabwe.
} 


\section{THE ECONOMETRIC METHODOLOGY}

This study adopts a four-stage econometric procedure to identify the direction of causality among the variables: First, panel unit root tests proposed by Levine, Lin et al. (2002), henceforth LLC, and Im, Pesaran et al. (2003), henceforth IPS, are undertaken to ascertain the order of integration of the variables. Second, conditional on finding that these variables are integrated of the same order, a panel cointegration test, based on Pedroni (1999, 2004), is employed to examine the existence of cointegrating relations. Third, in case that the variables are cointegrated, the cointegration vector among them is estimated using the Panel fully modified ordinary least square, based on Pedroni $(2000,2001)$. The final stage is to estimate a panel vector error correction model (VECM) in order to infer the Granger causal relations among the variables using the Generalized Method of Moments (GMM) estimator.

\section{1. Panel unit root tests}

Before proceeding to tests of cointegration to determine the long-run relationship among the variables in question, panel unit root tests for each of the variables need to be examined. Recent literature suggests that panel-based unit root tests have higher power than unit root tests based on individual time series. In this paper, two types of panel unit root tests that are more popular are employed. These tests are Levin, Lin et al. (LLC) (2002), and Im, Pesaran et al. (2003) tests. The LLC test assume that there is a common unit root process so that autoregressive coefficient $(\alpha)$ is identical across cross-sections. The test considers the following fundamental ADF specification:

$\Delta y_{i t}=\alpha y_{i t-1}+\sum_{j=1}^{p_{i}} \beta_{i j} \Delta y_{i t-j}+X_{i t}^{\prime} \delta+\varepsilon_{i t}$

where $y_{i t}$ is the series for cross-section $i$ in the panel over period $t, p_{i}$ is the number of lags selected for the ADF regression, the $\mathrm{X}_{\mathrm{it}}^{\prime}$ represent the exogenous variables in the model (i.e., fixed effects or individual time trend), and $\varepsilon_{i t}$ is the error term with independent idiosyncratic disturbance. The null and the alternate hypotheses are; $\mathrm{H}_{0}: \alpha=0$ and $\mathrm{H}_{1}: \alpha<0$. Under the null hypothesis, there is a unit root, while under the alternative, there is no unit root. In brief, the LLC calculates a proxy equation composed by the following two auxiliary regressions from which orthogonalized residuals are retrieved:

$$
\begin{aligned}
\Delta y_{i t} & =\sum_{j=1}^{p_{i}} \beta_{i j} \Delta y_{i t-j}+X_{i t}^{\prime} \delta+e_{i t} \\
y_{i t-1} & =\sum_{j=1}^{p_{i}} \beta_{i j} \Delta y_{i t-j}+X_{i t}^{\prime} \delta+v_{i t}
\end{aligned}
$$

The residuals obtained from estimating these equations ( $\hat{\mathrm{e}}_{i t}$ and $\left.\hat{\mathrm{v}}_{\mathrm{it}}\right)$ are further standardized with the respective regression standard error:

$$
\begin{aligned}
& \tilde{\mathrm{e}}_{\mathrm{it}}=\left(\hat{\mathrm{e}}_{\mathrm{it}} / \mathrm{s}_{\mathrm{i}}\right) \\
& \tilde{\mathrm{v}}_{\mathrm{it}}=\left(\hat{\mathrm{v}}_{\mathrm{it}} / \mathrm{s}_{\mathrm{i}}\right)
\end{aligned}
$$


where $s_{i}$ are the estimated standard errors from estimating each ADF in the equation (1). Finally the proxy equation is calculated:

$\tilde{\mathrm{e}}_{\mathrm{it}}=\alpha \tilde{\mathrm{v}}_{\mathrm{it}}+\eta_{\mathrm{it}}$

An estimate of the coefficient $\alpha$ may be obtained from this equation. The LLC obtain the following modified t-statistic for the estimated $\alpha(\widehat{\alpha})$ which is asymptotically normally distributed under the null hypothesis:

$t_{\alpha}^{*}=\frac{t_{\alpha}-(N \widetilde{T}) S_{N} \widehat{\sigma}^{-2} \operatorname{se}(\widehat{\alpha}) \mu_{m}^{*} \widetilde{T}}{\sigma_{m}^{*} \widetilde{T}} \rightarrow N(0,1)$

where $t_{\alpha}$ is the standard t-statistic for $\widehat{\alpha}=0, \widehat{\sigma}^{2}$ is the variance derived from the error term of the proxy equation, $S_{N}$ is the mean of the ratios of the long-run standard deviation to the innovation standard deviation for each individual, and $\widetilde{T}=T-\bar{P}-1$, where $\bar{P}$ is the mean lag order from the ADF regressions. The remaining two terms, $\mu_{\mathrm{m} \widetilde{\mathrm{T}}}^{*}$ and $\sigma_{\mathrm{m} \widetilde{\mathrm{T}}}^{*}$ are adjustment terms for the mean and standard deviation. The IPS test is based on the estimation of the following equation:

$\Delta y_{i t}=\alpha_{i} y_{i t-1}+\sum_{j=1}^{p_{i}} \beta_{i j} \Delta y_{i t-j}+X_{i t}^{\prime} \delta+\varepsilon_{i t}$

Unlike LLC test, this test allows the autoregressive coefficient to vary freely across crosssections. The null hypothesis of a unit root is $\mathrm{H}_{0}: \alpha_{\mathrm{i}}=0 \forall \mathrm{i}$ whereas the alternative hypothesis that at least one of the individual series in the panel is stationary may be written as,

$\mathrm{H}_{1}:\left\{\begin{array}{c}\alpha_{\mathrm{i}}=0 \quad \text { fori }=1,2, \ldots, \mathrm{N}_{1} \\ \alpha_{\mathrm{i}}<0 \text { fori }=\mathrm{N}_{1}+1, \mathrm{~N}_{1}+2, \ldots, \mathrm{N}\end{array} \quad\right.$ With $0<\mathrm{N}_{1} \leq \mathrm{N}$

Therefore, the null is rejected if there is a subset $\left(\mathrm{N}_{1}\right)$ of stationary individuals. IPS proposed two panel unit root statistics with heterogeneous dynamics based on the mean of the following individual unit root statistics: a Maximum Likelihood statistic called LM-bar and a Student statistic $\mathrm{t}-$ bar that is used in this paper. The $\mathrm{t}-$ bar statistic is performed as a simple average of the individual ADF t-statistics $\left(t_{i T}\left(p_{i}, \alpha_{i}\right)\right)$ for testing $\alpha_{i}=0$ in the equation (8):

$\mathrm{t}-\operatorname{bar}_{\mathrm{NT}}=\frac{\left(\sum_{\mathrm{i}=1}^{\mathrm{N}} \mathrm{t}_{\mathrm{iT}}\left(\mathrm{p}_{\mathrm{i}}, \alpha_{\mathrm{i}}\right)\right)}{\mathrm{N}}$

IPS assume that $t_{\mathrm{iT}}$ are i.i.d. and have finite mean and variance. Therefore, by LindebergLevy central limit theorem, the standardized t-bar statistic converges to a standard normal variate as $\mathrm{N} \rightarrow \infty$ under the null hypothesis. The results of LLC and IPS panel unit root tests for both levels and first differences of GDP, EX, and FDI are reported in Table (1).

The newly developed Modified Akaike's Information Criterion (MAIC), as suggested by $\mathrm{Ng}$ and Perron (2001), is adopted in order to select the optimal number of lag lengths based on the principle of parsimony. 
Table 1. Panel unit root tests results.

\begin{tabular}{|c|c|c|c|c|}
\hline Variable & $\begin{array}{l}\text { Panel } \\
\text { specifications }\end{array}$ & $\begin{array}{l}\text { Unit } \\
\text { root } \\
\text { tests }\end{array}$ & levels & $\begin{array}{l}\text { First } \\
\text { differences }\end{array}$ \\
\hline \multirow[t]{3}{*}{ GDP } & $\begin{array}{l}\text { Individual } \\
\text { intercept and } \\
\text { trend }\end{array}$ & $\begin{array}{l}\text { LLC } \\
\text { IPS }\end{array}$ & $\begin{array}{l}0.9988 \\
1.0000\end{array}$ & $\begin{array}{l}0.0000^{* * * *} \\
0.0000^{* * *}\end{array}$ \\
\hline & $\begin{array}{l}\text { Individual } \\
\text { intercept }\end{array}$ & $\begin{array}{l}\text { LLC } \\
\text { IPS }\end{array}$ & $\begin{array}{l}1.0000 \\
1.0000\end{array}$ & $\begin{array}{l}0.0000^{* * *} \\
0.0000^{* * *}\end{array}$ \\
\hline & None & LLC & 1.0000 & $0.0000 * * *$ \\
\hline \multirow[t]{3}{*}{ EX } & $\begin{array}{l}\text { Individual } \\
\text { intercept and } \\
\text { trend } \\
\end{array}$ & $\begin{array}{l}\text { LLC } \\
\text { IPS }\end{array}$ & $\begin{array}{l}0.9987 \\
0.9952\end{array}$ & $\begin{array}{l}0.0000^{* * *} \\
0.0000^{* * *}\end{array}$ \\
\hline & $\begin{array}{l}\text { Individual } \\
\text { intercept }\end{array}$ & $\begin{array}{l}\text { LLC } \\
\text { IPS }\end{array}$ & $\begin{array}{l}0.9789 \\
1.0000 \\
\end{array}$ & $\begin{array}{l}0.0000^{* * *} * \\
0.0000 * * *\end{array}$ \\
\hline & None & LLC & 1.0000 & $0.0000 * * *$ \\
\hline \multirow[t]{3}{*}{ FDI } & $\begin{array}{l}\text { Individual } \\
\text { intercept and } \\
\text { trend }\end{array}$ & $\begin{array}{l}\text { LLC } \\
\text { IPS }\end{array}$ & $\begin{array}{l}0.9022 \\
0.0428 * *\end{array}$ & $\begin{array}{l}0.0000^{* * *} \\
0.0000^{* * *}\end{array}$ \\
\hline & $\begin{array}{l}\text { Individual } \\
\text { intercept }\end{array}$ & $\begin{array}{l}\text { LLC } \\
\text { IPS }\end{array}$ & $\begin{array}{l}1.0000 \\
0.9993 \\
\end{array}$ & $\begin{array}{l}0.0000 * * * \\
0.0000 * * *\end{array}$ \\
\hline & None & LLC & 0.7266 & $0.0000 * * *$ \\
\hline
\end{tabular}

Notes: LLC and IPS represent the panel unit root tests of Levin, Lin et al. (2002); and Im, Pesaran et al. (2003) respectively. Selection of lags is based on Modified Akaike Information Criterion, Newey-West bandwidth selection using Bartlett kernel method. H0: Unit root. **, and *** indicate statistical significance at the $5 \%$, and $1 \%$ levels, respectively.

As shown in the table, for all three variables, the null hypothesis of a unit root in levels cannot be rejected significantly. However, upon taking first differences, the null of unit root is rejected at the $1 \%$ significance level, indicating that they are integrated of order one i.e., $\mathrm{I}(1)$.

\section{2. Panel cointegration tests}

Given that each of the variables is integrated of order one, we proceed to examine whether there is a long-run relationship among them using the panel cointegration tests suggested by Pedroni (1999, 2004). In order to recognize the existence of a cointegrating relationship among the variables, Pedroni $(1999,2004)$ examines statistical significance of $\gamma_{i}$ in the equation (11).

$$
\widehat{\varepsilon}_{\mathrm{it}}=\gamma_{\mathrm{i}} \hat{\varepsilon}_{\mathrm{it}-1}+\mathrm{u}_{\mathrm{it}}
$$


where $\hat{\varepsilon}_{\text {it }}$ denotes residuals derived from estimating the hypothesised cointegrating regression as follows:

$\mathrm{y}_{\mathrm{it}}=\alpha_{\mathrm{i}}+\delta_{\mathrm{i}} \mathrm{t}+\mathrm{x}_{\mathrm{it}}^{\prime} \beta_{\mathrm{i}}+\varepsilon_{\mathrm{it}}$ For $\mathrm{t}=1, \ldots, \mathrm{T}, \mathrm{i}=1, \ldots, \mathrm{N}$

where $\mathrm{T}$ is the time dimension and $\mathrm{N}$ the cross-sectional dimension, $\mathrm{x}_{\mathrm{it}}$ denotes a vector of regressors, $\beta_{i}$ is a vector of slope parameters. This formulation allows for considerable heterogeneity in the panel, since heterogeneous slope coefficients, fixed effects and individual specific deterministic trends are all permitted.

However, Pedroni $(1999,2004)$ has proposed seven cointegration tests that can be divided into two set. The first set (the panel cointegration statistics) is based on the withindimension approach, which includes four statistics: panel $v$-statistic, panel $\rho$-statistic, panel PP-statistic, and panel ADF-statistic.

The second set (the Group-Mean cointegration statistics), which includes three statistics: group $\rho$-statistic, group PP-statistic, and group ADF-statistic, is based on the between-dimension approach. The former are based on estimators that effectively pool the autoregressive coefficient across different members for the unit root tests on the estimated residuals, whereas the latter are based on estimators that simply average the individually estimated coefficients for each member $i$.

For the within-dimension statistics the test for the null of no cointegration is implemented as a residual-based test of the null hypothesis $\mathrm{H}_{0}: \gamma_{\mathrm{i}}=1$ for all $\mathrm{i}$, versus the alternative hypothesis $\mathrm{H}_{1}: \gamma_{\mathrm{i}}=\gamma<1$ for all $\mathrm{i}$, so that it presumes a common value for $\gamma_{\mathrm{i}}=$ $\gamma$. By contrast, for the between-dimension statistics the null of no cointegration is implemented as a residual-based test of the null hypothesis $\mathrm{H}_{0}: \gamma_{\mathrm{i}}=1$ for all $\mathrm{i}$, versus the alternative hypothesis $\mathrm{H}_{1}: \gamma_{\mathrm{i}}<1$ for all $\mathrm{i}$, so that it does not presume a common value for $\gamma_{\mathrm{i}}=\gamma$ under the alternative hypothesis. Thus, the between-dimension-based statistics allow one to model an additional source of potential heterogeneity across individual members of the panel (Pedroni (1999)).

According to above discussion, in this study, we investigate the cointegrating relationship among the variables of GDP, FDI, and EX through specifying and estimating of the following three equations:

$$
\begin{aligned}
& \mathrm{GDP}_{\mathrm{it}}=\alpha_{1 \mathrm{i}}+\delta_{1 \mathrm{i}} \mathrm{t}+\beta_{11 \mathrm{i}} \mathrm{FDI}_{\mathrm{it}}+\beta_{12 \mathrm{i}} \mathrm{EX}_{\mathrm{it}}+\varepsilon_{1 \mathrm{it}} \\
& \mathrm{FDI}_{\mathrm{it}}=\alpha_{2 \mathrm{i}}+\delta_{2 \mathrm{i}} \mathrm{t}+\beta_{21 \mathrm{i}} \mathrm{GDP}_{\mathrm{it}}+\beta_{22 \mathrm{i}} \mathrm{EX}_{\mathrm{it}}+\varepsilon_{2 \mathrm{it}} \\
& \mathrm{EX}_{\mathrm{it}}=\alpha_{3 \mathrm{i}}+\delta_{3 \mathrm{i}} \mathrm{t}+\beta_{31 \mathrm{i}} \mathrm{GDP}_{\mathrm{it}}+\beta_{32 \mathrm{i}} \mathrm{FDI}_{\mathrm{it}}+\varepsilon_{3 \mathrm{it}}
\end{aligned}
$$

The results of Pedroni panel cointegration test based on seven test statistics for specifications both with and without trend are tabulated in Table 2.

The results show that at least three out of seven testing statistics significantly reject the null hypothesis of no cointegration at the significance levels of $1 \%, 5 \%$ or $10 \%$ with GDP, FDI, and EX as dependent variable.

Therefore, we conclude that there exists evidence of a long-run relationship among economic growth, foreign domestic investment inflows, and exports goods and services in all the specifications. 
Table 2. Panel cointegration tests.

\begin{tabular}{|c|c|c|c|c|c|c|}
\hline \multirow{3}{*}{\begin{tabular}{|l|}
$\begin{array}{l}\text { Test } \\
\text { statistics }\end{array}$ \\
Within- \\
dimension:
\end{tabular}} & \multicolumn{6}{|c|}{ Dependent Variables } \\
\hline & \multicolumn{2}{|c|}{$\mathrm{EX}$} & \multicolumn{2}{|c|}{ FDI } & \multicolumn{2}{|c|}{ GDP } \\
\hline & With trend & $\begin{array}{l}\text { without } \\
\text { trend }\end{array}$ & With trend & without trend & With trend & $\begin{array}{l}\text { without } \\
\text { trend }\end{array}$ \\
\hline $\begin{array}{l}\text { Panel v- } \\
\text { Statistic }\end{array}$ & $\begin{array}{l}0.22646 \\
(0.3888)\end{array}$ & $\begin{array}{l}-0.92677 \\
(0.2597)\end{array}$ & $\begin{array}{l}-2.86604 * * * \\
(0.0066)\end{array}$ & $\begin{array}{l}1.38872 \\
(0.1521)\end{array}$ & $\begin{array}{l}5.48704 * * * \\
(0.0000)\end{array}$ & $\begin{array}{l}1.53804 \\
(0.1222)\end{array}$ \\
\hline $\begin{array}{l}\text { Panel rho- } \\
\text { Statistic }\end{array}$ & $\begin{array}{l}1.15439 \\
(0.2049)\end{array}$ & $\begin{array}{l}1.91892^{*} \\
(0.0633)\end{array}$ & $\begin{array}{l}0.24098 \\
(0.3875)\end{array}$ & \begin{tabular}{|l}
-1.44937 \\
$(0.1393)$
\end{tabular} & $\begin{array}{l}3.94210^{* * *} \\
(0.0002)\end{array}$ & \begin{tabular}{|l}
0.38879 \\
$(0.3699)$
\end{tabular} \\
\hline $\begin{array}{l}\text { Panel PP- } \\
\text { Statistic }\end{array}$ & $\begin{array}{l}-4.58224 * * * \\
(0.0000)\end{array}$ & \begin{tabular}{|l}
-0.38624 \\
$(0.3703)$ \\
\end{tabular} & $\begin{array}{l}-6.05336^{* * * *} \\
(0.0000)\end{array}$ & $\begin{array}{l}-4.83794^{* * *} \\
(0.0000)\end{array}$ & $\begin{array}{l}1.08181 \\
(0.2222) \\
\end{array}$ & $\begin{array}{l}-2.40193 * * \\
(0.0223) \\
\end{array}$ \\
\hline $\begin{array}{l}\text { Panel ADF- } \\
\text { Statistic }\end{array}$ & $\begin{array}{l}-6.97962 * * * \\
(0.0000)\end{array}$ & $\begin{array}{l}-2.45219 * * \\
(0.0197)\end{array}$ & $\begin{array}{l}-5.29345^{* * *} \\
(0.0000)\end{array}$ & $\begin{array}{l}-9.30140 * * * \\
(0.0000)\end{array}$ & $\begin{array}{l}-0.60028 \\
(0.3332)\end{array}$ & \begin{tabular}{|l}
$-2.11044^{* *}$ \\
$(0.0430)$
\end{tabular} \\
\hline \multicolumn{7}{|c|}{ Between dimension: } \\
\hline $\begin{array}{l}\text { Group rho- } \\
\text { Statistic }\end{array}$ & \begin{tabular}{|l}
$3.94844^{* * *}$ \\
$(0.0002)$ \\
\end{tabular} & \begin{tabular}{|l|}
$2.97577 * * *$ \\
$(0.0048)$ \\
\end{tabular} & \begin{tabular}{|l|}
-0.23860 \\
$(0.3877)$ \\
\end{tabular} & \begin{tabular}{|l}
$-3.35605^{* * *}$ \\
$(0.0014)$ \\
\end{tabular} & \begin{tabular}{|l|}
$5.72059^{* * *}$ \\
$(0.0000)$
\end{tabular} & \begin{tabular}{|l}
$2.96890^{* * *}$ \\
$(0.0049)$ \\
\end{tabular} \\
\hline $\begin{array}{l}\text { Group PP- } \\
\text { Statistic }\end{array}$ & $\begin{array}{l}-2.70101^{* *} \\
(0.0104)\end{array}$ & $\begin{array}{l}-2.33005 * * \\
(0.0264)\end{array}$ & $\begin{array}{l}-17.45903 * * * \\
(0.0000)\end{array}$ & $\begin{array}{l}-15.86089 * * * \\
(0.0000)\end{array}$ & $\begin{array}{l}-0.19293 \\
(0.3916)\end{array}$ & $\begin{array}{l}-1.61043 \\
(0.1091)\end{array}$ \\
\hline $\begin{array}{l}\text { Group } \\
\text { ADF- } \\
\text { Statistic }\end{array}$ & $\begin{array}{l}-4.59805^{* * *} \\
(0.0000)\end{array}$ & $\begin{array}{l}-3.99145^{* * *} \\
(0.0001)\end{array}$ & $\begin{array}{l}-13.98895^{* * *} \\
(0.0000)\end{array}$ & $\begin{array}{l}-10.49779 * * * \\
(0.0000)\end{array}$ & $\begin{array}{l}-1.18552 \\
(0.1976)\end{array}$ & $\begin{array}{l}-1.65122 \\
(0.1021)\end{array}$ \\
\hline
\end{tabular}

Notes: All tests statistics are asymptotically distributed as $\mathrm{N}(0,1) .{ }^{*},{ }^{* *}$, and ${ }^{* * *}$ indicate statistical significant at the $10 \%, 5 \%$, and $1 \%$ levels, respectively. The probabilities are reported in parentheses. All tests are one-sided tests: for the panel variance test the right tail of the standard normal distribution is used to reject the null of no cointegration and for the other six tests the left tail is used.

\section{3. Estimation of the cointegrating vectors}

Having established the likelihood that there is a cointegrating relationship among the variables when GDP, FDI or EX is regarded as dependent variable, the next step is to estimate the equilibrium vectors for heterogeneous cointegrated panels. Pedroni $(2000,2001)$ shows that the ordinary least squares (OLS) estimator for the cointegrating vector is asymptotically biased and that its standardized distribution depends upon nuisance parameters associated with the serial correlation structure of the data, and there is no reason to believe that this would be otherwise for the panel OLS estimator. Thus, he proposes the fully modified ordinary least squares (FMOLS) estimators to estimate the cointegrating vector once the variables under consideration have been found to be cointegrated. The FMOLS estimators accommodate considerable heterogeneity across individual members of the panel. One of these estimators is Group-Mean FMOLS (GMFMOLS).

The starting point for GMFMOLS is the equation (12), where

$x_{i t}=x_{i t-1}+\mu_{i t}$

And the vector process $\xi_{\mathrm{it}}=\left(\varepsilon_{\mathrm{it}}, \mu_{\mathrm{it}}\right)^{\prime}$ is stationary with asymptotic covariance matrix $\Omega_{\mathrm{i}}$. The GMFMOLS estimator for the equation (12) given by:

$\hat{\beta}_{\mathrm{GM}}^{\mathrm{FMOLS}}=\mathrm{N}^{-1} \sum_{\mathrm{i}=1}^{\mathrm{N}} \hat{\beta}_{\mathrm{i}}^{\mathrm{FMOLS}}$ 
There $\widehat{\beta}_{\mathrm{i}}^{\text {FMOLS }}$ is the conventional FMOLS time series estimate for $\mathrm{i}^{\text {th }}$ cross-section of the panel and is calculated as:

$\hat{\beta}_{\mathrm{i}}^{\mathrm{FMOLS}}=\left[\sum_{\mathrm{t}=1}^{\mathrm{T}}\left(\mathrm{x}_{\mathrm{it}}-\overline{\mathrm{x}}_{\mathrm{i}}\right)^{\prime}\left(\mathrm{x}_{\mathrm{it}}-\overline{\mathrm{x}}_{\mathrm{i}}\right)\right]^{-1}\left[\sum_{\mathrm{t}=1}^{\mathrm{T}}\left(\mathrm{x}_{\mathrm{it}}-\overline{\mathrm{x}}_{\mathrm{i}}\right)\left(\mathrm{y}_{\mathrm{it}}-\overline{\mathrm{y}}_{\mathrm{i}}\right)^{*}-\mathrm{T} \hat{\gamma}_{\mathrm{i}}\right]$

where

$\left(\mathrm{y}_{\mathrm{it}}-\overline{\mathrm{y}}_{\mathrm{i}}\right)^{*}=\left(\mathrm{y}_{\mathrm{it}}-\overline{\mathrm{y}}_{\mathrm{i}}\right)-\frac{\widehat{\Omega}_{21 \mathrm{i}}}{\widehat{\Omega}_{22 \mathrm{i}}} \Delta \mathrm{x}_{\mathrm{it}}$

$\hat{\gamma}_{\mathrm{i}}=\widehat{\Gamma}_{21 \mathrm{i}}+\widehat{\Omega}_{21 \mathrm{i}}^{\mathrm{o}}-\frac{\widehat{\Omega}_{21 \mathrm{i}}}{\widehat{\Omega}_{22 \mathrm{i}}}\left(\widehat{\Gamma}_{22 \mathrm{i}}+\widehat{\Omega}_{22 \mathrm{i}}^{\mathrm{o}}\right)$

$\hat{\gamma}_{\mathrm{i}}$ act to correct for the effect of serial correlation due to transitional dynamics. It is composed of elements from the long run covariance matrix between the estimated residuals, $\hat{\varepsilon}_{\text {it }}$, from the panel regression (12), and $\Delta \mathrm{x}_{\mathrm{it}}$. Specifically, the long run covariance matrix between these series is denoted as $\Omega_{\mathrm{i}}$ which can be decomposed as $\Omega_{\mathrm{i}}=\Omega_{\mathrm{i}}^{\mathrm{o}}+\Gamma_{\mathrm{i}}+\Gamma_{\mathrm{i}}^{\prime}$, where $\Omega_{\mathrm{i}}^{\mathrm{o}}$ is the contemporaneous covariance and $\Gamma_{\mathrm{i}}$ is a weighted sum of autocovariances. Following Pedroni $(2000,2001)$, we employ the Group-Mean FMOLS estimator to obtain long-run cointegrating vectors we detected in the equations (13), (14), and (15).The results are summarized in Table3.

Table 3. Panel Fully Modified OLS estimates.

\begin{tabular}{|c|c|c|c|}
\hline \multirow{2}{*}{ Coefficients $\downarrow$} & \multicolumn{3}{|c|}{ Dependent variable } \\
\cline { 2 - 4 } & GDP & FDI & EX \\
\hline \multirow{2}{*}{$\widehat{\boldsymbol{\beta}}_{\mathbf{1}}$} & $2.896455^{* * *}$ & $0.068672^{* * *}$ & $0.001677^{* * *}$ \\
& $(13.3237)$ & $(-261.9075)$ & $(-2234.3181)$ \\
\hline$\widehat{\boldsymbol{\beta}}_{\mathbf{2}}$ & $0.556046^{* * *}$ & $-1.436094^{* * *}$ & $0.010989^{* * *}$ \\
& $(3.1943)$ & $(-7.9082)$ & $(-413.5183)$ \\
\hline
\end{tabular}

Notes: The values of the t-statistics are reported in parentheses. *** denotes statistical significance at the $1 \%$ level.

As can be seen from this Table, the coefficients $\beta$ in all three equations are statistically significant at the $1 \%$ level. The residuals obtained from estimating the regressions will be included in the panel VECM as the error correction terms (ECTs).

\section{4. Panel Granger causality}

Following Granger (1988) we estimate a vector error correction model(VECM) rather than a Vector autoregression(VAR) model for the Granger causality test, since the VAR model is misspecified in the presence of cointegration. A panel-based dynamic VECM in a multivariate context can be specified as the following regressions:

$$
\Delta \mathrm{GDP}_{\mathrm{it}}=\alpha_{1}+\sum_{\mathrm{j}=1}^{\mathrm{m}} \beta_{1 \mathrm{j}} \Delta \mathrm{GDP}_{\mathrm{it}-\mathrm{j}}+\sum_{\mathrm{j}=1}^{\mathrm{m}} \delta_{1 \mathrm{j}} \Delta \mathrm{FDI}_{\mathrm{it}-\mathrm{j}}+\sum_{\mathrm{j}=1}^{\mathrm{m}} \gamma_{1 \mathrm{j}} \Delta \mathrm{EX}_{\mathrm{it}-\mathrm{j}}+\lambda_{1} \mathrm{ECT}_{\mathrm{it}-1}^{\mathrm{g}}+\varepsilon_{1 \mathrm{it}}
$$




$$
\begin{aligned}
& \Delta \mathrm{FDI}_{i t}=\alpha_{2}+\sum_{j=1}^{\mathrm{m}} \beta_{2 \mathrm{j}} \Delta \mathrm{GDP}_{\mathrm{it}-\mathrm{j}}+\sum_{\mathrm{j}=1}^{\mathrm{m}} \delta_{2 \mathrm{j}} \Delta \mathrm{FDI}_{\mathrm{it}-\mathrm{j}}+\sum_{\mathrm{j}=1}^{\mathrm{m}} \gamma_{2 \mathrm{j}} \Delta \mathrm{EX}_{\mathrm{it}-\mathrm{j}}+\lambda_{2} \mathrm{ECT}_{\mathrm{it}-1}^{\mathrm{f}}+\varepsilon_{2 \mathrm{it}}(20) \\
& \Delta \mathrm{EX}_{\mathrm{it}}=\alpha_{3}+\sum_{\mathrm{j}=1}^{\mathrm{m}} \beta_{3 \mathrm{j}} \Delta \mathrm{GDP}_{\mathrm{it}-\mathrm{j}}+\sum_{\mathrm{j}=1}^{\mathrm{m}} \delta_{3 \mathrm{j}} \Delta \mathrm{FDI}_{\mathrm{it}-\mathrm{j}}+\sum_{\mathrm{j}=1}^{\mathrm{m}} \gamma_{3 \mathrm{j}} \Delta \mathrm{EX}_{\mathrm{it}-\mathrm{j}}+\lambda_{3} \mathrm{ECT}_{\mathrm{it}-1}^{\mathrm{e}}+\varepsilon_{3 \mathrm{it}}(21)
\end{aligned}
$$

where all variables are as previously defined, $\Delta$ is the lag operator, $m$ denotes the lag length, $\varepsilon_{\mathrm{it}}=\mu_{\mathrm{i}}+\eta_{\mathrm{t}}+\mathrm{v}_{\mathrm{it}}$ are disturbance terms assumed to be uncorrelated with mean zero, $\mathrm{ECT}_{\mathrm{it}-1}^{\mathrm{g}}, \mathrm{ECT}_{\mathrm{it}-1}^{\mathrm{f}}$, and $\mathrm{ECT}_{\mathrm{it}-1}^{\mathrm{e}}$ are the lagged error correction terms derived from the long-run cointegrating vectors associated to equations (13), (14), and (15) respectively. The coefficients of ECTs represent how fast deviations from the long-run equilibrium are eliminated following changes in each variable. The statistical significance of the coefficients of the independent variables in equations (19), (20), and (21) provides evidence on the source of causation. In this section, first, by examining the significance of coefficients of respective interactive terms (namely, the lagged variables of each VECM variable), we evaluate Granger weak causality. Acoording to Masih and Masih (1996) and Asafu-Adjaye (2000) the weak Granger causality is a short-run causality in the sense that the dependent variable responds only to short term shocks to the stochastic environment. Next, presence (or absence) of longrun causality is established by testing on the significance of the coefficient of the ECT, $\lambda$, in each equation. Finally, it is also desirable to check whether the two sources of causation are jointly significant, in order to test for Granger causality. This can be done by joint testing on the ECTs and respective interactive terms (Oh and Lee (2004)). The joint test indicates which variable(s) bear the burden of short run adjustment to re-establish long run equilibrium, following a shock to the system (asafu-adjaye (2000)).

Equations (19), (20), and (21) are the standard dynamic panel data specifications. In such models, one can show that the OLS estimator will be seriously biased due to correlation of the lagged dependent variable with the individual specific effects. Taking first differences eliminates the individual specific effects, but this creates a correlation between the transformed dependent variable and transformed error term due to the lagged variables on the right-hand side. Arellano and Bond (1991) argue that the first differenced model should be estimated by Generalized Method of Moments (GMM) estimator using appropriately lagged level variables as instruments. Later, it is shown that lagged levels provide weak instruments for first differences in some situations. For this reason, an alternative to first differencing GMM estimator is given by Arellano and Bover (1995) based on "forward orthogonal deviations" which in common with first differencing eliminates individual effects but in contrast it does not introduce serial correlation in the transformed errors. In this GMM estimator, the level variables lagged two and earlier can be used as instruments. We therefore apply the orthogonal deviations technique proposed by Arellano and Bover (1995) to estimate the parameters of the VECM. With respect to the usage of one-step or two-step estimator, we focus on the one-step estimator because the later may give seriously misleading standard errors (See Arellano and Bond (1991); Blundell and Bond (1998)). In case of the number of selected lags, we estimate two VECM with one and two lags for each variable for several reasons: first, as mentioned by Meier and Hicklin (2009), in theory, one uses an infinite number of lags in Granger causality, but in practice one or two lags are usually sufficient. Second, the Schwarz and Akaike information criteria suggest one or two lags as the optimal number of lags in each equation. Third, this model was also estimated up to five lags and 
results were not significantly different. Panel Granger causality test results are reported in Tables 4 and 5. The period dummy variables are commonly specified to control for period fixed effects. The validity of the instrument set in each regression was tested using The Sargan's (1958) test of over-identifying restrictions and the null hypothesis of the validity of the instruments could not be rejected. The Sargan statistic is asymptotically distributed as Chi-Square under the null of the instrumental validity.

Table 4. Panel Granger causality test results (With one lag for each variable).

\begin{tabular}{|c|c|c|c|c|c|c|c|}
\hline \multirow{2}{*}{$\begin{array}{c}\text { Dependent } \\
\text { variable } \\
\downarrow\end{array}$} & \multicolumn{4}{|c|}{ Short-run } & Long-run & \multicolumn{3}{c|}{ Strong causality } \\
\cline { 2 - 8 } & $\Delta \mathrm{GDP}$ & $\Delta \mathrm{FDI}$ & $\Delta \mathrm{EX}$ & $\mathrm{ECT}$ & $\begin{array}{c}\text { Joint } \\
\text { (ECT and } \\
\Delta \mathrm{GDP})\end{array}$ & $\begin{array}{c}\text { Joint } \\
(\mathrm{ECT} \text { and } \\
\Delta \mathrm{FDI})\end{array}$ & $\begin{array}{c}\text { Joint } \\
(\mathrm{ECT} \text { and } \\
\Delta \mathrm{EX})\end{array}$ \\
\hline$\Delta$ GDP & - & $(1.8682)^{*}$ & $(3.1952)^{* * *}$ & $(-2.5682)^{* *}$ & - & {$[7.3381]^{* * *}$} & {$[6.4712]^{* * *}$} \\
\hline$\Delta$ FDI & $(1.1688)$ & - & $(0.7889)$ & $(-6.1591)^{* * *}$ & {$[20.5585]^{* * *}$} & - & {$[19.5560]^{* * *}$} \\
\hline$\Delta \mathbf{E X}$ & $(1.7288)^{*}$ & $(-0.4891)$ & - & $(-0.8138)$ & {$[1.8276]$} & {$[0.6007]$} & - \\
\hline
\end{tabular}

Notes: the values reported in parentheses are t-statistics, the values reported in square brackets are F-statistics, *, **, and *** indicate statistical significant at the $10 \%, 5 \%$, and $1 \%$ levels, respectively.

Table 5. Panel Granger causality test results (With two lags for each variable).

\begin{tabular}{|c|c|c|c|c|c|c|c|}
\hline \multirow{3}{*}{$\begin{array}{c}\text { Dependent } \\
\text { variable } \\
\downarrow\end{array}$} & \multicolumn{7}{|c|}{ Sources of causation (independent variables) } \\
\hline & \multicolumn{3}{|c|}{ Short-run } & \multirow{2}{*}{$\begin{array}{c}\text { Long-run } \\
\text { ECT }\end{array}$} & \multicolumn{3}{|c|}{ Strong causality } \\
\hline & $\Delta \mathrm{GDP}$ & $\Delta \mathrm{FDI}$ & $\Delta \mathrm{EX}$ & & $\begin{array}{c}\text { Joint } \\
\text { (ECT and } \\
\Delta \text { GDP) } \\
\end{array}$ & $\begin{array}{c}\text { Joint } \\
\text { (ECT and } \\
\Delta \mathrm{FDI}) \\
\end{array}$ & $\begin{array}{c}\text { Joint } \\
\text { (ECT and } \\
\Delta \mathrm{EX}) \\
\end{array}$ \\
\hline$\Delta$ GDP & - & {$[3.9973]^{* *}$} & {$[5.2951]^{* * *}$} & $(-2.4367)^{* *}$ & - & {$[4.4922]^{* * *}$} & {$[3.8084]^{* * *}$} \\
\hline$\Delta$ FDI & {$[0.3472]$} & - & {$[0.3965]$} & $(-3.9166)^{* * *}$ & {$[8.8741]^{* * *}$} & - & {$[8.8458]^{* * *}$} \\
\hline$\Delta \mathbf{E X}$ & {$[0.6513]$} & {$[0.8007]$} & - & $(-0.8938)$ & [1.0083] & [1.0318] & - \\
\hline
\end{tabular}

Notes: the values reported in parentheses are t-statistics, the values reported in square brackets are F-statistics, *, $* *$, and $* * *$ indicate statistical significant at the $10 \%, 5 \%$, and $1 \%$ levels, respectively.

As it can be seen from the tables, the causality test results are alike for both models. In the long-run equilibrium, EX and FDI Granger cause GDP, and also EX and GDP do it for FDI. In the short-run, the results provide evidence of causality running from EX and FDI to GDP. On the other hand, GDP and FDI do not cause EX in either the short run or the long run. Finally, the results of the strong causality are parallel to those of the long run causality.

\section{CONCLUDING REMARKS}

This paper uses recently developed econometric techniques such as panel unit roots tests, panel cointegration, and panel generalized method of moment (GMM) to investigate the existence and the nature of the dynamic causal relationships among GDP, exports, and Foreign Direct Investment (FDI) inflows for 57 developing countries from 1980 to 2007. The findings reveal that in the long-run equilibrium, exports and FDI inflows Granger cause GDP, 
and also exports and GDP do it for FDI inflows. The results also provide evidence of shortrun causality running from exports and FDI inflows to GDP. On the other hand, GDP and FDI inflows do not cause exports in either the short run or the long run. Finally, the results of the strong causality are parallel to those of the long run causality.On the basis of the obtained results, it is recommended that outward-oriented strategies and policies of attracting FDI be pursued by developing countries to achieve higher rates of economic growth. On the other hand, the countries can increase FDI inflows by stimulating their economic growth

\section{References}

[1] Aitken, B., G. H. Hanson, et al., 1997. "Spillovers, Foreign Investment, and Export Behavior." Journal of International Economics 43, pp. 103-132.

[2] Aizenman, J. and I. Noy, 2006. "FDI and tradeTwo-way linkages?" The Quarterly Review of Economics and Finance 46(3): 317-337.

[3] Alguacil, M., A. Cuadros, et al., 2002. "Foreign direct investment, exports and Domestic Performance in Mexico: a causality analysis." Economics Letters 77(3), pp. 371-376.

[4] Arellano, M. and O. Bover, 1995. "Another Look at the Instrumental-Variable Estimation of Error Components Models." Journal of Econometrics 58, pp. 29-52.

[5] Arellano, M. and B. Stephen, 1991. "Some Tests of Specification for Panel Data: Monte Carlo Evidence and an Application of Employment Equations." Review of Economic Studies 58, pp. 277-297.

[6] Asafu-Adjaye, J., 2000. "The Relationship Between Energy Consumption, Energy Prices and Economic Growth: Time Series Evidence from Asian Developing Countries." Energy Economics 22, pp. 615-625.

[7] Bahmani-Oskooee, M. and M. Oyolola, 2007. "Export growth and output growth: an application of bounds testing approach", ." Journal of Economics and Finance 31, pp. $1-11$.

[8] Balaguer, J. and M. Cantavella-Jorda, 2001. "Examining the export-led growth hypothesis for Spain in the last century." Applied Economics Letters 8, pp. 681-685.

[9] Balassa, B., 1978. "Exports and economic growth: further evidence." Journal of Development Economics 5, pp. 181-189.

[10] Balasubramanyam, V. N., M. Salisu, et al., 1996. "Foreign Direct Investment and Growth in EP and IS Countries." The Economic Journal 106, pp. 92-105.

[11] Basu, P., C. Chakraborty, et al., 2003. "Liberalization, FDI and Growth in Developing Countries: A Panel Cointegration Approach." Economic Inquiry 14(3), pp. 510-516.

[12] Biswal, B. and U. Dhawan, 1998. "Export-led growth hypothesis: cointegration and causality analysis for Taiwan." Applied Economics Letters 5, pp. 699-701.

[13] Blomström, M. and A. Kokko, 1998. "Multinational Corporations and Spillovers." Journal of Economic Surveys 12, pp. 247-277.

[14] Blundell, R. and S. Bond, 1998. "Initial Conditions and Moment Restrictions in Dynamic Panel Data Models." Journal of Econometrics 87, pp. 115-43. 
[15] Borensztein, E., J. De Gregorio, et al., 1998. "How does foreign direct investment affect economic growth." Journal of International Economics 45, pp. 115-135.

[16] Borenztein, E., J. De Gregorio, et al., 1998. "How does foreign direct investment affect economic growth." Journal of International Economics 45, pp. 115-135.

[17] Buffie, E., 1992. "On the condition for export-led growth." Canadian Journal of Economics 25, pp. 211-225.

[18] Chakraborty, C. and P. Basu, 2002. "Foreign direct investment and growth in India: A cointegration approach." Applied Economics 34(9), pp. 1061-1073.

[19] Choe, J. I., 2003. "Do Foreign Direct Investment and Gross Domestic Investment Promote Economic Growth?" Review of Development Economics 7(1), pp. 44-57.

[20] Chowdhury, A. and G. Mavrotas, 2006. "FDI and Growth: What Causes What? ." The World Economy 29(1), pp. 9-19.

[21] De Mello, L. R., 1999. "Foreign direct investment-led growth: evidence from time series and panel data." Oxford Economic Papers (51), pp. 133-151.

[22] Dees, S., 1998. "Foreign direct investment in China: determinants and effects, ." Economics of Planning 31(2-3), pp. 175-194.

[23] Ekanayake, E., R. Vogel, et al., 2003. "Openness and Economic Growth: Empirical Evidence on The Relationship between Output, Inward FDI, and Trade." Journal of Business Strategies 20, pp. 59-7.

[24] Ekanayake, E. M., 1999. "Exports and Economic Growth in Asian Developing Countries: Cointegration and Error-Correction Models." Journal of Economic Development 24(2), pp. 43-56.

[25] Ericsson, J. and M. Irandoust, 2001. "On the Causality between Foreign Direct Investment and Output: a Comparative Study." The International Trade Journal 15 ,pp. 122-132.

[26] Feder, G., 1982. "On exports and economic growth." Journal of Development Economics 12, pp. 59-73.

[27] Granger, C. W. J., 1988. "Some recent developments in a concept of causality." Journal of Econometrics 39, pp.199-211.

[28] Hansen, H. and J. Rand, 2006. "On the Causal Links between FDI and Growth in Developing Countries." World Economy 29(1), pp. 21-41.

[29] Herzer, D., S. Klasen, et al., 2006. "In Search of FDI-Led Growth in Developing Countries." Ibero-America Institute for Economic Research Discussion Papers, No. 150 , Goettingen, Germany.

[30] Hsiao, C. and Y. Shen, 2003. "Foreign direct investment and Economic growth: The importance of institutions and urbanization." Economic Development \& Cultural Change 51(4), pp. 124-132.

[31] Hsiao, F. S. T. and M.-C. W. Hsiao, 2006. "FDI, Exports and GDP in East and Southeast Asia - Panel Data Versus Time-Series Causality Analysis." Journal of Asian Economics 17, pp. 1082-1106. 
[32] Im, K. S., M. H. Pesaran, et al., 2003. "Testing for unit roots in heterogeneous panels." Journal of Econometrics 115(1), pp. 53-74.

[33] Islam, M., 1998. "Export expansion and economic growth: testing for cointegration and causality." Applied Economics 30, pp. 415-425.

[34] Jun, K. W. and H. Singh, 1996. "The Determinants of Foreign Direct Investment in Developing Countries." Transnational Corporations 5(2), pp. 67-105.

[35] Jung, W. S. and P. J. Marshall, 1985. " Exports, Growth and Causality in Developing Countries." Journal of Development Economics 18, pp. 1-12.

[36] Kaldor, N., 1976. "Strategic Factors in Economic Development." Cornell University Press, Ithaca, New York, USA.

[37] Kohpaiboon, A., 2003. "Foreign Trade Regimes and FDI Growth Nexus: A Case Study of Thailand." The Journal of Development Studies 40(2), pp. 5-69.

[38] Krugman, P. R., 1984. "Import protection as export promotion. In Monopolistic Competition in International Trade." ed. H. Kierzkowski, Oxford: Oxford University Press.

[39] Kudrle, R. T. and D. B. Bobrow, 1982. "US policy toward Foreign Direct Invesment." World Politics 34(3), pp. 353-79.

[40] Lancaster, K., 1980. "Intra-industry trade under perfect monopolistic competition." Journal of International Economics 10, pp. 151-175.

[41] Lean, H. H., 2008. "The Impact of Foreign Direct Investment on the Growth of the Manufacturing Sector in Malaysia." International Applied Economics and Management Letters 1(1), pp.41-45

[42] Leichenko, R. M. and R. A. Erickson, 1997. "Foreign Direct Investment and State Export Performance." Journal of Regional Science 37(2), pp. 307-329.

[43] Levin, A., C. Lin, et al., 2002. "Unit Root Tests in Panel Data: Asymptotic and FiniteSample Properties." Journal of Econometrics 108: 1-24.

[44] Li, X. and X. Liu, 2005. "Foreign Direct Investment and Economic Growth: An Increasingly Endogenous Relationship." World Development 33(3), pp. 393-407.

[45] Liu, X., P. Burridge, et al., 2002. "Relationships between economic growth, foreign direct investment and trade: evidence from China." Applied Economics 34, pp. 14331440 .

[46] Liu, X., S. Chang, et al., 2009. "Trade, foregin direct investment and economic growth in asian countries." Applied Economics 41, pp. 1603-1612.

[47] Love, J. and R. Chandra, 2005. "Testing Export-led Growth in South Asia, Journal of Economic Studies." 32, pp. 132-145.

[48] Lutz, S. and O. Talavera, 2004. "Do Ukrainian firms benefit from FDI?" Economics of Planning 37, pp. 77-98.

[49] Mah, J. S., 2005. "Export expansion, economic growth and causality in China." Applied Economics Letters 12, pp. 105-107. 
[50] Makki, S. and A. Somwaru, 2004. "Impact of Foreign Direct Investment and Trade on Economic Growth: Evidence from Developing Countries." AJAE 86, pp. 795-801.

[51] Markusen, J. R. and A. J. Venables, 1998. "Multinational Firms and the New Trade Theory." Journal of International Economics 46, pp. 183-204.

[52] Masih, A. M. M. and R. Masih, 1997. "On the Temporal Causal Relationship Between Energy Consumption, Real Income, and Prices: Some New Evidence From AsianEnergy Dependent Nics Based on A Multivariate Cointegration/Vector ErrorCorrection Approach." Journal of Policy Modeling 19(4), pp. 417-440.

[53] McKinnon, R., 1964. "Foreign exchange constraints in economic development and efficient aid allocation." Economic Journal 74, pp. 388-409.

[54] Meier, K. J. and A. Hicklin, 2008. "Employee Turnover and Organizational Performance: Testing a Hypothesis from Classical Public Administration." Journal of Public Administration Research and Theory 18(4), pp. 573-590.

[55] Nair-Reichert, U. and D. Weinhold, 2000. "Causality Tests for Cross-Country Panels: New look at FDI and Economic Growth in Developing Countries." Oxford Bulletin of Economics and Statistics 64, pp. 153-171.

[56] Ng, S. and p. Perron, 2001. "Lag Length Selection and the Construction of Unit Root Tests with Good Size and Power." Econometrica 69, pp. 1519-1554.

[57] Pedroni, P., 1999. "Critical values for cointegration tests in heterogeneous panels with multiple regressors." Oxford Bulletin of Economics and Statistics 61, pp. 653-670.

[58] Pedroni, P., 2000. "Full modified OLS for heterogeneous cointegrated panels. Nonstationary Panels Panel Cointegration and Dynamic Panels." Advances in Econometrics 15. JAI Press.

[59] Pedroni, P., 2001. "Purchasing Power Parity Tests in Cointegrated Panels"." Review of Economics and Statistics 83, pp. 727-731.

[60] Pedroni, P. 2004. "Panel Cointegration: Asymptotic and Finite Sample Properties of Pooled Time Series Tests with an Application to the PPP Hypothesis." Econometric Theory 20, pp. 597-625.

[61] Reppas, P. A. and D. K. Christopoulos, 2005. "The export-output growth nexus: Evidence from African and Asian countries." Journal of Policy Modeling 27, pp. 929940.

[62] Sargan, J. D., 1958. "The estimation of economic relationships using instrumental variables." Econometrica 26, pp. 397-415.

[63] Shan, J. and F. Sun, 1998. "On the export-led growth hypothesis: the econometric evidence from China." Applied Economics 30, pp. 1055-1065.

[64] Sharma, K., 2000. "Export Growth in India: Has FDI Played a Role?" Center Discussion Paper, No. 816, Economic Growth Center, Yale University.

[65] Toda, H. Y. and Yamamoto, 1995. "Statistical inference in Vector Autoregressions with possibly integrated processes." Journal of Econometrics 66, pp. 225-250. 
[66] Yamada, H. and H. Y. Toda, 1998. "Inference in Possibly Integrated Vector. Autoregressive Models: Some Finite Sample Evidence." Journal of Econometrics 86, pp. 55-95.

[67] Zhang, K. H., 2001. "Does Foreign Direct Investment Promote Economic Growth? Evidence form East Asia and Latin America." Contemporary Economic Policy 19(2), pp. $175-185$.

[68] Zhang, Q. and B. Felmingham, 2001. "The relationship between inward direct foreign investment and China's provincial export trade." China Economic Review 12(1), pp. 8299. 